\title{
Review and Extension on Ambidexterity: A Theoretical Model Integrating Networks and Absorptive Capacity
}

\author{
Avimanyu Datta \\ Department of Entrepreneurship and Information Systems, Todd Hall 442 \\ College of Business, Washington State University \\ Pullman, WA 99164-4743, USA \\ Tel: +1-509-335-5051Ｆax:+1-509-335-5339Ｅ-mail: adatta@wsu.edu
}

Received: November 29, 2010 Accepted: December 10,2010 doi:10.5430/jms.v2n1p2

\begin{abstract}
We provided an integrative model linking ambidexterity, absorptive capacity and networks. External networks, measured through centrality and multiplexity, and internal networks through behavioral context, dual structure and top management teams affect an organization's ambidexterity. In addition, multiplexity positively affects an organization's realized and potential absorptive capacity, while centrality has an inverse-u relationship with potential and a positive relation with realized absorptive capacity. Also, internal networks through coordination, capabilities and socialization capabilities affect an organization realized and potential absorptive capacity. Realized absorptive capacity positively affects ambidexterity, while potential absorptive capacity moderates the relationship between realized absorptive capacity and ambidexterity. In posing our model, it was assumed that the operating environment of the firm remains constant. We generate propositions on these relationships for empirical testing and further theoretical insights.
\end{abstract}

Keywords: Ambidexterity, Exploration, Exploitation, Networks, Centrality, Multiplexity, Potential Absorptive Capacity, Realized Absorptive Capacity

\section{Introduction}

From a very generic standpoint, ambidexterity is about striking a balance (Bodwell \& Chermack, 2009; Collin \& Porras, 1997; Eisenhardt, 2000; Lewis, 2000) rather than choosing between two extremes. Such ability leads a firm to create emerging markets while not affecting its traditional ones. For example, Hewlett Packard continued to come up with leading for its mainstream computing and printing markets, while investing heavily in the emerging IT service markets with releases like Open View. Another example would be Nokia's experiment with newer technology resulting in a vast array of new mobile technology product, while continuing to make its pricing and other product decisions in order to remain the dominant cellular handset provider. Past research has confirmed that ambidextrous organizations are naturally innovative and have the ability to renew themselves by creating breakthrough products for existing markets and capitalizing on emerging markets (Brikinshaw \& Gibson, 2004; Gibson \& Birkinshaw, 2004; O'Reilly \& Tushman, 2004; Raisch \& Birkinshaw, 2008; Tushman \& O’Reilly, 1996a, 2002; Volberda \& Lewin, 2003).

Ambidextrous organizations are those that are capable of exploiting their existing competencies while exploring new opportunities (Bodwell \& Chermack, 2009; Lubatkin, Simsek, \& Veiga, 2006; March, 1991; O'Reilly \& Tushman, 2007). Past research has positively linked a balance between exploration and exploitation with organizational self-renewal through constant innovations in volatile business environment. In addition, a number of studies have posited that a balance between exploration and exploitation leads not only to organizational renewal but also, helps firms to become more innovative and, as a result, such firms are more long-lived (Tushman \& O'Reilly, 2002). Literature has also cited that an increasing a firm's absorptive capacity can lead to organizational renewal (Narasimhan, Rajiv, \& Dutta, 2006). The rapid rate of knowledge obsolescence in many high-technology markets makes it imperative for firms to renew their technological bases constantly (Narasimhan, et al., 2006). While, an increase of a firm's absorptive capacity will lead to renewal of technological bases, whose exploration in addition to continuous exploitation of existing technological bases leads to ambidexterity. Notwithstanding a few key works (Jansen, Vanden Bosch, \& Volberda, 2005a, 2005b, 2006), the literature on absorptive capacity has kept ambidexterity at largely at bay. Successful are those firms that can continuously explore new technologies and markets, while maintaining their exploitive stance with existing markets and technologies (O’Reilly \& Tushman, 2004; Tushman \& O’Reilly, 1996b, 2002). To be ambidextrous, firms need to 
expand on their capacity to process information, which by definition is absorptive capacity. In addition, knowledge of emerging markets and technologies comes from networks external to the firm's boundaries (Ahuja, 2000; Ahuja \& Katila, 2001; Ahuja \& Lampert, 2001; Phelps, 2003, 2010; Schilling \& Phelps, 2007). Despite the benefits, such networks may cripple a firm with information overload, and success often times lie in the firm's ability to develop and routinize information filters, internally (Simsek, 2009).

There has been some disjoint efforts to link networks with ambidexterity (Birkinshaw \& Gibson, 2004; Simsek, 2009; Simsek, Heavey, Veiga, \& Souder, 2009; Tushman \& O’Reilly, 1996b) and with absorptive capacity (W. M. Cohen \& D. A. Levinthal, 1990; Lane, Koka, \& Pathak, 2006; Lane \& Lubatkin, 1998; Lane, Salk, \& Lyles, 2001; Todorova \& Durisin, 2007; Zahra \& George, 2002). We believe an integral view will help us a more comprehensive understanding on the antecedents of ambidexterity and their interplay with each other. This is particularly important since there is a continued theoretical interest in ambidexterity, whereby the assumptions and boundary conditions need to be assessed, and the interplay between the antecedents and moderators need to be evaluated. Further, literature has shown that ambidexterity leads to higher firm performance (Birkinshaw \& Gibson, 2004; Birkinshaw, Hood, \& Young, 2005; Gibson \& Birkinshaw, 2004; O'Reilly \& Tushman, 2007; O'Reilly \& Tushman, 2004; Tushman \& O’Reilly, 1996b). Such an integrative view merges the gap between three constructs of interests whereby research in each area can enrich themselves by incorporating concepts from each other. For instance, research on networks can see increase in absorptive capacity and attainment exploration of emerging markets and technologies as a positive outcome. Such an integrative view will also extend our understanding of knowledge transfer through integration of complimentary knowledge and technologies, especially absorptive capacity and relative absorptive capacity (W. M. Cohen \& D. A. Levinthal, 1990; Lane \& Lubatkin, 1998) by means of networks.

Although ambidexterity is the central construct of this paper, yet our discussions on the relationships between networks and absorptive capacities helped us getting a more comprehensive view. This work merges the gap between three constructs of interests whereby research in each area can enrich themselves by incorporating concepts from each other. However, we are not claiming that that posited model is an all encompassing view of ambidexterity. Instead, it is a step toward generating an integrative view by integrating, synthesizing and expanding on the existing literature. In posing our model, we have assumed that the operating environment in terms of turbulence, complexity and dynamism (Dess \& Beard, 1984) remains constant. Further, in underscoring the relationship external networks have with ambidexterity and absorptive capacity, we held internal networks constant, and vice versa.

The rest of this paper is organized as follows. In the next section we shed some light on past research on ambidexterity. The following section comprises our theoretical model. We began by drawing boundaries and restricting our definition on ambidexterity, followed by discussing external and internal networks, absorptive capacity and linking them by generating propositions. Our theoretical model is illustrated below (Figure 1) to ease the assimilation of discussion. We also include a table of definitions of our constructs (Table 1) and a table summarizing our propositions (Table 2). We conclude with a discussion of conclusion and implications for future research.

$<$ Figure 1, Table 1 and Table 2 about here $>$

\section{Previous Work on Ambidexterity}

Ambidexterity is frequently depicted using a variety of oppositional concepts. The most accepted definition of ambidexterity in the current literature is a balance between explorations and exploitation. These organizations are capable of exploiting their existing competencies while exploring new opportunities at the same time (Bodwell \& Chermack, 2009; Lubatkin, et al., 2006; March, 1991; O'Reilly \& Tushman, 2007). March (1991) referred to this as the exploration of new possibilities and the exploitation of old certainties. Specifically, he mentioned:

Exploitation includes such things as refinement, choice, production, efficiency, selection, implementation, execution. Adaptive systems that engage in exploration to the exclusion of exploitation are likely to find that they suffer the costs of experimentation without gaining many of its benefits. They exhibit too many undeveloped new ideas and too little distinctive competence. Conversely, systems that engage in exploitation to the exclusion of exploration are likely to find themselves trapped in suboptimal stable equilibrium. As a result, maintaining an appropriate balance between exploration and exploitation is a primary factor in system survival and prosperity. (March, 1991).

Similar to March's (1991) assertion is the balance between adaptability and agility as depicted by Birkinshaw and Gibson (2004). They defined the trade-offs between alignment and adaptability as foundational to organizations and describe organization ambidexterity as the capacity to simultaneously achieve alignment (excellence in daily operations) and adaptability (referring to the organization's ability to innovate and change in response to changing demands in the environment). To ensure long-term success, an organization needs to master both adaptability and alignment - a dual 
mode, known as ambidexterity (Birkinshaw \& Gibson, 2004; Gibson \& Birkinshaw, 2004; Hansen \& Birkinshaw, 2007; Hill \& Birkinshaw, 2006; Raisch \& Birkinshaw, 2008).

For example, while Nokia launched a vast array of new mobile technology product offerings, it also continued to make pricing and other product-product decisions in order to sustain its position as one of the leading handset providers (Birkinshaw \& Gibson, 2004). Focusing too much on alignment makes an organization lose long-term vision, while emphasizing adaptability over alignment means building tomorrow's business at the cost of today's (Birkinshaw \& Gibson, 2004; Gibson \& Birkinshaw, 2004). Similarly, in order to innovate successfully, organizations must balance two stages of innovation, namely: initiation and implementation - again termed as ambidexterity (Duncan, 1976). Specifically, during the initiation phase, an organization needs low formalization and low centralization, whereas during implementation phase it tends to follow high formalization with low complexity and high centralization.

Seen from Birkinshaw and Gibson's (2004) perspective, March's exploration would be substantiated by Nokia's experiment with newer technology and exploitation would be their continuing investment and commitment in their existing product lines. Exploration encompasses knowledge creation and analysis of emerging and future opportunities, while exploitation is defined as making use of existing knowledge to leverage current opportunities (March, 1991; Sidhu, Commandeur, \& Volberda, 2007; Sidhu, Volberda, \& Commandeur, 2004; Wielemaker, 2003; Zack, 1999, 2003).

Other scholars have used different words to attribute similar oppositional meanings of the concepts relevant to the notion of organizational ambidexterity. For example:

1. The paradox of administration involves the dual searches for certainty and flexibility (Thompson, 1967).

2. Ambidexterity is an acceptable solution to the battle between efficiency (exploitation activities) and flexibility (exploration activities) (Adler, Goldoftas, \& Levine, 1999).

3. Ambidextrous organizations as those able to reconcile agility and stability (Vinekar, Slinkman, \& Nerur, 2006). In their view, an agility approach is suitable for projects with high levels of uncertainty and risk and frequently changing environments. A stability approach is appropriate for projects in which the requirements are stable and predictable, and when the project is large, critical, and complex. But firms that pursue both anticipatory and hindsight actions at the same time enable managers to exercise better strategic control and optimize the firm's short-run performance as well as long-term prospects.

4. Strategic planning activities can be anticipatory or hindsight in orientation. Anticipatory activities seek to proactively take advantage of the future in order to reduce the organization's environmental uncertainty (Veliyath, 1992). Hindsight activities rely on ex-post analysis of events and information to prepare for the future (Veliyath, 1992).

5. Ambidexterity as a balance between incremental and innovation and change (Tushman \& O'Reilly, 1996b).

6. Ability to maintain superior performance in established business, while managing innovation in targeted areas (Nadler \& Tushman, 1999).

\section{Theoretical Model}

\subsection{Ambidexterity: A Balance of two Opposing Phenomena}

A common thread that runs through all the seemingly varied views on ambidexterity is that instead of choosing between the two extreme ends of a spectrum, ambidexterity is about striking a 'balance' (Bodwell \& Chermack, 2009; Collin \& Porras, 1997; Eisenhardt, 2000; Lewis, 2000). In other words, it is about balancing seemingly contradictory tensions be it exploration \& exploitation, adaptability \& agility, initiation \& implementation, emergent \& deliberate, radical \& incremental innovations and so forth. While exploration, adaptability, initiation, radical and emergent are explorative ends of the spectrum; exploitation, agility, implementation, incremental and deliberate are exploitative ends of the spectrum. Concentrating only on one aspect would help us address the core of ambidexterity: balance between opposing forces. For the purpose of this paper we chose exploration and exploitation. We thus define and restrict our definition of ambidexterity as the property of an organization to balance the two activities of exploration and exploitation. Exploration requires significant investments with uncertain payoffs (Bodwell \& Chermack, 2009; Siggelkow \& Levinthal, 2003). Exploitation focuses on incremental change to create value through existing competencies, and thus poses less risk to the organization. Exploitation is an orientation to the short-term whereas exploration has a more future-based, or long-term focus (Bodwell \& Chermack, 2009; He \& Wong, 2004). Exploitation activities may be directed toward gaining efficiency while exploration activities promote flexibility in the organization. The exploration versus exploitation construct has been used in a "wide range of management research areas, including strategic management, organization theory, and managerial economics (Bodwell \& Chermack, 2009; He \& Wong, 2004). 
Past research has positively linked a balance between exploration and exploitation with organizational self-renewal through constant innovations in volatile business environment (Hamel \& Getz, 2004 ; Handy, 1990; Huber \& Glick, 1993; Levinthal, 1997; Levinthal \& March, 1993; Lewin \& Volberda, 1999; March, 1991; Nahapiet \& Ghoshal, 1998; Volberda, 1998; Volberda \& Lewin, 2003). In addition, a number of studies have posited that a balance between exploration and exploitation leads not only to organizational renewal but also, helps firms to become more innovative and, as a result, such firms are more long-lived (Dess \& Beard, 1984; Hamel \& Getz, 2004 ; Hamel \& Prahalad, 2002; Levinthal, 1997; Levinthal \& March, 1993; Lewin \& Volberda, 1999; March, 1991; Volberda, 1998; Volberda \& Lewin, 2003). The precise amount of exploitation or exploration a company needs is, however, not specified in the existing literature. While too much time spent on exploration can drive out exploitation, the more common situation in organizations is that "exploitation tends to drive out exploration", due to focus on daily operations (Levinthal \& March, 1993).

There are four ways to strike a balance between exploration and exploitation: harmonic, cyclical, partitional and reciprocal (Simsek, 2009; Simsek, et al., 2009). Harmonic balance is achieved through concurrently pursuing exploitation and exploration harmoniously within a single organizational unit (Simsek, et al., 2009). Such a balance competes for scarce resources, leading to conflicts, contradictions, and inconsistencies. Organizational practice and routines are viable antecedents of harmonic balance.

Cyclical ambidexterity is a type of balance in which organizations engage in long periods of exploitation (or relative stability), interspersed by sporadic episodes of exploration (or change). Simsek, et al. (2009), related it to punctuated equilibrium (Gersick, 1991). Antecedents to cyclical ambidexterity are found in human resource practices that emphasize innovation, teamwork, and flexibility (Simsek, et al., 2009).

Simsek, et al. (2009) traced back partitional ambidexterity to Duncan's (1976) work, on the role of dual structure of initiation and implementation. Organizational theorist (O'Reilly \& Tushman, 2004; Tushman \& O'Reilly, 1996a) envision partitional ambidexterity as an interdependent, simultaneous phenomenon, involving the compartmentalizing and synchronizing of exploitation and exploration within different structural units an organization. From a structural perspective, partitional ambidexterity is achieved by creating separate units or divisions for exploitation and exploration (Duncan, 1976; O'Reilly \& Tushman, 2004; Tushman \& O'Reilly, 1996a), with each unit embodying distinct strategic and operating logics, cultures, and incentive systems. The ability to simultaneously pursue both exploitation and exploration results from "hosting multiple contradictory structures, processes, and cultures within the same firm" (O'Reilly \& Tushman, 2004). While tightly integrated at the business unit level, these logics must remain loosely coupled across business units (Benner \& Tushman, 2003). In addition, Simsek, et al. (2009) suggested antecedents to partitional ambidexterity that extend across organizations by using external networks. In a study of almost 20,000 alliances over a period of ten years, it observed that exploitation and exploration can be pursued both within and across three domains of strategic alliances including the value chain function of alliances, the attributes of alliance partners, and the network position of alliance partners (Lavie \& Rosenkopf, 2006).

Reciprocal interdependence occurs when the outputs of exploitation from a business unit become the inputs for exploration by a second business unit and the outputs of second business unit cycle back to become the inputs of the first business unit (Simsek, et al., 2009). Ongoing information exchange between organizational units or between organizations enables this. Firms appear to balance their tendencies to explore and exploit with respect to the nature of their alliances or choice of partners over time and across domains (Lavie \& Rosenkopf, 2006). Their findings highlight the significance of alliances and external networks as mechanisms for combining exploitation and exploration across time and units. In this vein, knowledge integration among alliance partners may be especially relevant to the pursuit of this form of ambidexterity (Simsek, et al., 2009).

The ability of ambidextrous firms to come up with radical new products without hampering the existing markets, make them long-lived (O'Reilly \& Tushman, 2004; Tushman \& O'Reilly, 1996a, 2002). Long lived-firms have several structural and cultural similarities (Collin \& Porras, 1999; Huygens, Van Den Bosh, Volberda, \& Baden-Fuller, 2001; Porter, 1998; Van Wijk, 2003). Factors within firms that affect ambidexterity include decentralization, a tolerant management style, and sensitivity towards the emerging trends in the environment. Combining work on corporate longevity and co-evolutionary theory, Volberda and Lewin (2003) proposed three key principles of self renewal within organizations: (a) self-renewing organizations focus on managing requisite variety by regulating internal rates of change equal to or exceed external rate of environmental change triggered by customer orientation, technology innovation, industry competition, and product obsolescence; (b) self-renewing organizations optimize self-reorganization; and (c) self-renewing organizations synchronize concurrent exploitation and exploration (Levinthal, 1997; Levinthal \& March, 1993; Lewin \& Volberda, 1999; March, 1991). 
Thus, the balance between exploration and exploitation arises from sensitivity to the environment and maintaining a compatible organizational structure, which in turn produces organizational longevity. Organizations that are capable of simultaneously building new capabilities and using existing capabilities, (i.e., harmonic ambidexterity) enjoyed higher levels of venture strategic performance through the creation of breakthrough innovations by investing in disruptive technologies (Hill \& Birkinshaw, 2006). Technologically oriented organizations that engage in successive or cyclic rounds of exploitation and exploration are best equipped to pursue product innovations (Simsek, 2009; Simsek, et al., 2009; Tushman \& O'Reilly, 1996b). By engaging in intensive periods of exploration, business units discover new technologies that not only spur the proliferation of new products, but that may even become established as the dominant design in the industry (Henderson \& Clark, 1990). Then, by subsequently shifting to exploitation, business units improve the performance of product innovations through process innovation (Simsek, et al., 2009). Partitional ambidextrous were successful in launching breakthrough products and services and in ensuring the continued high performance of existing products (O'Reilly \& Tushman, 2004).

The key to firm longevity is in being innovative (O'Reilly \& Tushman, 2004; Tushman \& O'Reilly, 1996a, 2002). From the discussion of types of balance it can be concluded that ambidextrous organizations are naturally innovative and have the ability to renew themselves by creating breakthrough products for existing markets and capitalizing on emerging markets (Brikinshaw \& Gibson, 2004; Gibson \& Birkinshaw, 2004; O’Reilly \& Tushman, 2004; Raisch \& Birkinshaw, 2008; Tushman \& O'Reilly, 1996a, 2002; Volberda \& Lewin, 2003). Specifically, such organizations have been able to compete in mature market segments through incremental innovations (Abernathy \& Utterback, 1978; C.M. Christensen, 1992a; C.M. Christensen, 1992b) and in emerging market segments through radical innovations (Abernathy \& Utterback, 1978; R. Burgelman, A. \& Grove, 1996; Robert A. Burgelman, 2002; R.A. Burgelman, Christensen, \& Wheelright., 2006; C.M. Christensen, 1992a; Galunic \& Eisenhardt, 1996; Henderson \& Clark, 1990). Being ambidextrous enables a firm to diversify its skills to combine current opportunities with future vision. For instance, the ability of Hewlett Packard to balance its mainstream computing and printing market with emerging IT service markets led to leading products in computers, printers and IT services like HP Open View.

Large corporations, such as Johnson and Johnson, and Asea Brown Boveri (ABB), have been able to compete in mature market segments through incremental innovation, and in emerging market segments through discontinuous innovation (Tushman \& O'Reilly, 1996a). Like a juggler who needs to handle multiple markers simultaneously (Tushman \& O'Reilly, 1996b), the companies reconcile conflicting demands from their task environment and synchronize and balance concurrent exploration of new opportunities and exploitation of existing ones (Brikinshaw \& Gibson, 2004; Duncan, 1976; Gibson \& Birkinshaw, 2004; O’Reilly \& Tushman, 2004; Tushman \& O’Reilly, 1996a). In this way, ambidextrous organizations can renew themselves through the creation of breakthrough products, services and processes without destroying or hampering their traditional businesses (Gibson \& Birkinshaw, 2004; Tushman \& O'Reilly, 1996a; Volberda \& Lewin, 2003)

\subsection{External and Internal Networks}

Social networks, external networks and internal networks are considered three different, albeit complementary, types of networks focusing on different levels of analysis, using different theoretical constructs, and explain different outcomes of networks (Van Wijk, 2003). For the propose of this paper we will only consider internal and external networks and disregard the impact of social networks on any of the constructs. External network research focuses on networks as a governance mode intermediating markets and hierarchies - e.g., joint-ventures and strategic alliances. External network research highlights the competitive dimension of networks and therefore, focuses in particular on performance issues (Dyer \& Singh, 1998). Internal network literature investigates intra-organizational structure and processes and management roles required for knowledge creation and sharing, maintaining flexibility, and enabling self-renewal (Volberda, 1998; Volberda \& Lewin, 2003). While there is a clear distinction between focus of these networks, their outcomes can overlap. For instance, internal networks enable organizational self renewal, but it is not clear whether the influence of other networks were isolated while studying self-renewal (Volberda \& Lewin, 2003). It is not clear what organizational scholars are talking about when they use the term external networks (Provan, Fish, \& Sydow, 2007). The term interorganizational network is used interchangeably with strategic alliances, coalitions, and cooperative arrangements, and has been tied to resource dependence theory (Pfeffer \& Salancik, 1978; Provan, et al., 2007), transaction cost economics (Provan, et al., 2007; Williamson, 1991), and interorganizational contracts (Ariño \& Reuer, 2006; Provan, et al., 2007). Despite these differences all definitions of external networks refer to common themes including social interaction, relationships, connectedness, collaboration, collective action, trust, and cooperation (Provan, et al., 2007). Other common themes include business ecosystems (Moore, 1993) and clusters (Porter, 1998). Although great strides have been made in the study of external networks, a shared language with definite concrete meanings in the study of network has not yet been developed (Provan, et al., 2007). 
The definition of networks could range from being very generic to extremely specific. From a generic standpoint, a network can be considered as a set of nodes and the set of ties representing some relationship, or lack of relationship, between the nodes (Brass, Galaskiewicz, \& Greve, 2004), while from a specific standpoint, it includes different types of external networks and, how each is different within the rubric of networks as being constellations of organizations that come together through the establishment of social contracts or agreements (Barringer \& Harrison, 2000).

Organizations enter alliances with each other to access critical resources, but they rely on information from the network of prior alliances to determine with whom to cooperate (Gulati \& Gargiulo, 1999). These new alliances modify the existing network, prompting an endogenous dynamic between organizational action and network structure that drives the emergence of external networks". While networks are formed to access and share resources (Dyer \& Singh, 1998; Gnyawali, He, \& Madhvan, 2006; Gulati, 1998; Gulati \& Kletter, 2005; Gulati, Nohria, \& Zaheer, 2000; Klein, Rai, \& Straub, 2007; Pfeffer \& Salancik, 1978), they become valuable resources in their own right (Barney, 1991; Mata, Fuerst, \& Barney, 1995; Melville, Kraemer, \& Gurbaxani, 2004; Porter, 1998).

The importance of networks on multiple levels has been specified in understanding firm innovations (Gupta, Tesluk, \& Taylor, 2007). An organization's climate of innovation emerges from the shared perception of members of the organization on the degree to which organizational policies, resources, procedures and practices support and encourage innovation (Gupta, et al., 2007). The characteristics of an organization's network of relations are relevant to a firm's ability to balance explorations and exploitations (Nohria, 1992; Nohria \& Eccles, 1992). Synthesizing the above, we therefore define networks as the collective of structures, and collaboration, within and between organizations, and between organizations and innovation engines. From an external network standpoint this includes business clusters, partnerships, business ecosystems, and relationships with innovation engines. From the standpoint of intraorganizational or internal networks, it includes organizational structure, top management teams, and behavioral context comprising performance management and social support. These networks themselves become a valuable resource, enabling organizational flexibility and leading to self-renewal.

\subsubsection{External Networks and Ambidexterity}

In our discussion of the types of balance, we found that ambidexterity is enabled by the networks (Birkinshaw \& Gibson, 2004; Gibson \& Birkinshaw, 2004; Raisch \& Birkinshaw, 2008). Collaboration within and among organizations and between organizations and innovation engines affects an organization's ability to strike a balance between exploration and exploitation. From a very specific standpoint, multiplexity and centrality (or diversity) of networks affect ambidexterity (Simsek, 2009; Simsek, et al., 2009). Network diversity affords the organization multiple benefits from the perspectives of attaining ambidexterity. First, it affords the organization with the benefit of heterogeneity in its problem-solving machinery (Simsek, 2009). An organization that has a homogenous network has little opportunity to consider multiple perspectives because most network members see the world similarly. In contrast, diverse ties imply organizations that may differ in their modes of reasoning, problem formulation and solution. Exposure to these different approaches adds to the repertoire that the organization can bring to bear on exploitation and exploration. For example, it may lead to constructive conflict, yielding deeper and more comprehensive analysis of design problems, and novel framing of opportunities (Baum, Calabrese, \& Silverman, 2000; Beckman \& Haunschild, 2002; Simsek, 2009). Second, diverse network ties are valuable to ambidexterity because they can help the organization overcome the familiarity trap, that is, a tendency to favor the familiar over the unfamiliar (Ahuja \& Lampert, 2001; Simsek, 2009). Third, diverse ties can also promote ambidexterity by enabling organizations overcome the convenience trap, a tendency to search for solutions that are in the neighborhood of existing solutions rather than search for completely new solutions (Ahuja \& Lampert, 2001; Simsek, 2009). Diverse ties enable the organization to access a wider circle of information about potential markets, new business opportunities, innovations, and sources of capital, and potential customers. Thus, an organization with heterogeneous partners is likely to not only have access to more complementary resources but also to know more about how to productively put these resources into use (Burt, 1992; Simsek, 2009). For example, through its strong relation with universities in Finland, Nokia is able to experiment with a vast array of new mobile technology inventions (such as the Nokia Symbian operating system) relatively inexpensively, while continuing to invest in being the dominant handset franchise, thereby enabling its ambidexterity (Birkinshaw \& Gibson, 2004). The above discussion leads us to propose:

\section{Proposition 1a: Multiplexity of ties among organizations and with innovation engines positively affects ambidexterity.}

Central organizations, because of their more numerous direct and indirect connections to others, have more relationships to draw upon in obtaining resources and so are less dependent on any single organization to explore (Scott, 1991). In addition, the access facilitated by centrality means a higher likelihood of exposure to the various disparate social circles 
within the network and to more clusters, or pockets, of highly connected organizations (Walter. W Powell, Koput, \& Smith-Doerr, 1996; Simsek, 2009). As a consequence, exploitation is also enabled because central organizations become better informed about what is going on in the network. Centrality is likely to present information and resource advantages that are beneficial to the attainment of ambidexterity (Simsek, 2009). An organization that is centrally located in a network with respect to others is likely to expect greater benefits in terms of knowledge spillovers, information flows and innovations by peripheral actors (Bell, 2005; Walter. W Powell, et al., 1996; Soh, 2003). Since central organizations have direct or indirect relationships, they can explore and access resources through multiple relationships and thus are less dependent on any single entity (Scott, 1991; Simsek, 2009). Further, exploitation is also enhanced because central organizations are well informed about what is going on in the networks (Simsek, 2009), for instance which are the key resources for manufacturing, distribution channels and so forth. Organizations become well informed by centrality through higher likelihood of exposure to contrasting social circles (Simsek, 2009). On the negative side, there may be a diminishing point of returns to centrality (Simsek, 2009). The existence of an inflection point in the relationship between centrality and ambidexterity is related to allocation of attention and information overload (Simsek, 2009). This is particularly true when the size of the network is very high or when the network is very dense, or when there are many entities in a network. From the standpoint of allocation of attention, it can be argued that, centrality might pull organizations into several directions (Scott, 1991; Simsek, 2009) because central organizations over a large network can spend limited amount of time to each contacts. Thus, intensity of contacts diminishes and useful resources and information are less likely to surface (Simsek, 2009). Large quantities of information originating from diverse sources, can overload an organizations information processing capacity. Owing to organization's the limited information processing capacity, information overload arising from networks may be counter-productive. To counteract this, organizations would develop and routinize information filters and focus on certain type of information, while disregarding others (Simsek, 2009). Thus, organizations when information munificence is low, organizations process less information; when moderate, highest amount of information is processed; and when, cognitive strain leads to reversing to less amount of information processing (Koka \& Prescott, 2002; Simsek, 2009). Thus, centrality has an inverse U shaped relationship with respect to ambidexterity. When the network size is small or too large, there will no or diminishing returns, while at a moderate size of network, centrality can positively affect ambidexterity. This leads us to propose:

Proposition 1b: Centrality has an inverted u-shaped relationship with ambidexterity. Such that at moderate levels of network population, ambidexterity is maximized.

\subsubsection{Internal Networks and Ambidexterity}

From the standpoint of internal networks, decentralized structure, a common culture and vision, and supportive leaders and flexible managers are key sources of ambidexterity (Tushman \& O'Reilly, 1996b). Other aspects of intraorganizational networks considered were roles of dual structures, behavioral context and top management teams (Simsek, 2009).

Attributes of organizational structural architecture affects its ability to attain ambidexterity (Simsek, 2009). Specific to this was the concept of duality, where some business units focus entirely on exploration and some on exploitation. Such a structure leads to parallel attainment of exploration and exploitation, without conflict for resources. From an interorganizational standpoint networks with innovation engines too gives a temporal separation of exploration and exploitation, where the innovations explored by innovation engines are exploited by the organization. In presence of a dual structure, organizations are more likely to extract from its network and ties information and knowledge pertinent to ambidexterity (Simsek, 2009). From a specific standpoint, dual structure minimizes the negative impact of information overloading on ambidexterity that central organizations from a large network experiences (Simsek, 2009). The reason is small and decentralized exploratory units will more effectively extract exploratory information while more centralized tight cultures and processes of exploitation units will extract exploitative information. Thus, while moderate levels of centrality are most conducive to ambidexterity, this relationship is strengthened in presence of dual structure. In the same vein, dual structural architectures provide organizations with enhanced capabilities to handle information influx from diverse or multiplex or diverse networks. In presence of the dual structure, the cost and effort to handle information flood from diverse networks is controlled (Simsek, 2009). With diversity of ties, the cost of technological and organizational challenges to integration increases. In fact, more diverse the knowledge the more complex is the problem of creating and managing integration. With dual structures, an organization can boost its ability to identify valuable knowledge, develop connections and combine information that promotes ambidexterity (Simsek, 2009). Combining the arguments relating to the roles of dual structure on centrality and multiplexity of networks, we propose: 
Proposition 1c: The dual structure architecture within firms positively moderates the relationship that interorganizational network through centrality and multiplexity has on ambidexterity.

An organizational behavioral context comprising performance management and social support enhances its ability to enhance ambidexterity (Gibson \& Birkinshaw, 2004). High performance organizational context is expected to balance performance management and social support (Birkinshaw \& Gibson, 2004). Organizational context as an important determinant of whether an organization can leverage opportunities of ambidexterity provided by centrality and multiplexity (Simsek, 2009). In a high performance context, an organization is dynamic and flexible enough to allow its members to pursue exploration and exploitation, both and which are scrutinized and rewarded (Simsek, 2009). Inductively speaking, therefore, positive impacts of centrality and multiplexity on ambidexterity are enhanced further in presence of high performance organizational context. Specifically, high performance context can dampen and strengthen the negative effects of high centrality and moderate centrality, and also amplify the positive effect of multiplexity on ambidexterity (Simsek, 2009). In other words, high performance organizational context plays a moderating role on the effect centrality and multiplexity has on ambidexterity. This leads us to propose:

\section{Proposition 1d: Behavioral Context within firms positively moderates the relationship between external networks through centrality and multiplexity on ambidexterity.}

Top management teams makes decisions regarding organizational forms, cultures and resource allocation processes to enable a balance between exploration and exploitation (Smith \& Tushman, 2005). Ambidexterity is facilitated by top management's internal processes which enable them to handle large amount of information ad decision alternatives and deal with conflict and ambiguity (Tushman \& O'Reilly, 1996b). Top management's behavioral integration is a key contributor to ambidexterity (Lubatkin, et al., 2006). Behavioral integration directly influences how top management teams deals with contradictory knowledge processes that support the accomplishment of an exploitation and exploratory orientation, such that the greater the integration greater is the realization of both (Lubatkin, et al., 2006; Simsek, 2009). Extending the work of Lubatkin et al. (2006), Simsek (2009) reasoned that top management teams play a fundamental role in modifying the impact of network centrality and multiplexity on ambidexterity. The top management team when behaviorally integrated, the resultant synchronization of social and task processes associated with collaborative behavior, quality of information exchange and joint decision making among senior executives can promote a deeper understanding and utilization of exploratory and exploitive opportunities, provided by network centrality and multiplexity (Simsek, 2009). Additionally, it is expected that behavioral integration will enable an organization to better manage diverse information and resource benefits associated with centrality and multiplexity (Simsek, 2009). Thus we posit:

Proposition 1e: The top management team within firms positively moderates the relationship between external networks through centrality and multiplexity on ambidexterity.

\subsection{Absorptive Capacity}

Absorptive capacity is the limit to the rate at which a firm can absorb scientific or technological information and/or a limit to the quantity of such information that can be absorbed (W. M. Cohen \& D. Levinthal, 1990; Jansen, 2005; Jansen, et al., 2005b). Conceptually, absorptive capacity is similar to information processing capacity but at the firm level rather than at the individual level. Absorptive capacity underlies a firm's knowledge capabilities by which the firm acquires, assimilates, transforms, and exploits knowledge resources to produce dynamic capabilities such as innovativeness (Zahra \& George, 2002). It is critical to developing competitive advantage and often leads to significant innovations (Walter. W Powell, et al., 1996). Todorova and Durisin (2007) conceptualized absorptive capacity as the capacity to recognize the value of knowledge, acquire, assimilate, transform, and exploit knowledge. Networks are salient to absorptive capacity and important for increasing a firm's knowledge base in conjunction with its business partners and for creating new knowledge, which can be observed in the form of new patents (which are embodiments of knowledge), new categories of products and services (which come from understanding the competition and market needs), and in extreme cases, creation of new industries (Jansen, et al., 2005b). Networks also play an important role in building a firm's absorptive capacity by providing skills and processing abilities that can support acquisition, assimilation, transformation, and exploitation of knowledge to create innovation (Alavi \& Leidner, 2001; Jansen, et al., 2005b; Lane, et al., 2006; Lane \& Lubatkin, 1998; Lane, et al., 2001; Todorova \& Durisin, 2007).

The primary antecedents to absorptive capacity, according to Cohen \& Levinthal (1990), lies in the structure of communication between organizations and entities (termed outward absorptive capacity), the structure of communication between subunits in the organization (termed cross-functional absorptive capacity), and the structure of communication within subunits in the organization (termed inward absorptive capacity). The latter is self evident insofar as good communication within units will permit more and quicker absorption of knowledge than will poor communication, but outward and functional absorptive capacity need some illustration and explanation. 
Examples of outward absorptive capacity are the strategic partnership between Intel and Microsoft (Grove, 1996) and the business ecosystem that Walmart created with its suppliers (R.A. Burgelman, et al., 2006; Moore, 1993) or the relationship that Nokia has with academic and research institutions. In each case the experiences or knowledge of one firm or entity increases the limit of absorption of the other entity over the network. An example of cross functional absorptive capacity is the tight linkage between design and manufacturing sub-units that has enabled Japanese manufacturing firms to move products rapidly from design through production, marketing, sales, and into the market (Clark \& Fujimoto, 1987; W. M. Cohen \& D. Levinthal, 1990). Overlapping product development cycles facilitated collaboration and coordination across subunits within a firm (Clark \& Fujimoto, 1987).

Zahra and George (2002) deconstructed absorptive capacity into potential and realized absorptive capacities. Potential absorptive capacity, which includes knowledge acquisition and assimilation, captures efforts expended in identifying and acquiring new external knowledge and in assimilating knowledge obtained from external sources (Zahra \& George, 2002). Realized absorptive capacity, which includes knowledge transformation and exploitation, encompasses deriving new insights and consequences from the combination of existing and newly acquired knowledge, and incorporating transformed knowledge into operations (Zahra \& George, 2002).

Absorption limits provide impetus for firms to develop internal R\&D capabilities. R\&D departments then not only perform their work along with lines with which they are already familiar, but also they can extend their work to include new ideas and, in particular, incorporate new knowledge that is external to the firm. Cohen and Levinthal (1990) argued that absorptive capacity enables firms to predict more accurately the mature and commercial potential of technological advances. In other words, a higher absorptive capacity and/or efforts to increase absorptive capacity can both promote innovation within a firm as well as a firm's ability to manage innovation effectively. In fact, realized absorptive capacity converts knowledge into products, services, and technologies (Jansen, 2005; Jansen, et al., 2005b). By the combination of potential and realized absorptive capacity firms increase the distinctiveness of their innovations (Yli-Renko, Autio, \& Sapienza, 2001) and are able to develop new innovations that differ substantially from existing products, services, and processes, without hampering existing lines.

\subsubsection{External Networks and Absorptive Capacity}

While discussing the impact of external networks on absorptive capacity we held the impact of internal on absorptive capacity constant. The external connections of a firm can facilitate the firm's learning capabilities (W. M. Cohen \& D. A. Levinthal, 1990). External sources including the firm's alliances, joint venture, and other formal relationships (e.g., with suppliers and consultants) provide key resources to the firm. The large number of external resources increases the firm's opportunity of exposure to diverse knowledge, which is critical to firm's absorptive capacity. Through the interaction with external sources, firms can identify new knowledge, obtain complementary knowledge, and integrate it into organization's routines. In addition to the informational advantages, the coordination and cooperation with several external sources simultaneously press the firm to improve its internal knowledge processes so as to exploit and sustain their relationship with the external sources. For example, to serve multiple customers with diverse requirements, the firm has to build the capability (e.g., customer management relationship systems) to understand their customers' needs. The firm will also need to develop routines to internalize the information they get from the customer. Thus, having more external sources provides access to richer information and an incentive for the firm to manage this knowledge spillover.

To expand on absorptive capacity, some previous fundamental knowledge is necessary and so fundamental research and/ or tie ups with professional research institute are crucial. Relationships between firms and firms with innovation engines affect a firm's absorptive capacity (W.M Cohen, Florida, Randazzes, \& Walsh, 1998; W. M. Cohen \& D. Levinthal, 1990; W. M. Cohen, Nelson, \& Walsh, 2002). In fact, taken from structural standpoint of external networks in terms of centrality and multiplexity both affects absorptive capacity.

Publications, public meetings and conferences, informal and personal exchanges of information, and consulting contracts appear to be the four primary channels for knowledge exchange between firms and innovation engines (W.M Cohen, et al., 1998). The relative importance of the channels may also vary across industries. Cohen et al., (1998) examined the channels of knowledge exchange and the relative importance of them based on a survey of 1478 U.S. R\&D lab managers in the manufacturing sector, and noted that within this sector some channels were preferred over others. Similarly, findings from R\&D collaboration within the context of the biotechnology industry (Oliver, 2004; Walter.W Powell, 1998; Salman \& Saives, 2005), and construction industries (Lin, Wang, \& Tserng, 2006)while Lin et al.(2006) showed idiosyncrasies in channel use within these sectors as well.

From these works, it appears that networks between academia and industry can benefit participating firms in that there is a useful flow of knowledge and, in some contractual cases, intellectual property itself from the innovation engine to the business partner either in the sharing of research findings and/or through the guidance of the scientist (e.g., if the 
scientist were to serve as an advisor or board member for the participating firm). These types of networks between firms and innovation engines expand an organization's absorptive capacity (W. M. Cohen \& D. A. Levinthal, 1990). Taking these arguments from the standpoint of multiplexity of networks, we argue that diverse networks can increase a firm's potential absorptive capacity. With a diverse network, a firm is able to able to acquire and assimilate knowledge from an assortment of sources which enhances its ability to process external knowledge. In fact, acquisition of external knowledge from external sources is part of the definition of potential absorptive capacity by Zahra and George (2002). A firm that resides within a homogenous network is crippled in terms of absorbing multiple perspectives of a problem or a solution domain. Diverse or multiplex of ties enables a firm to gather information from multiple sources and therefore increases the probability of acquisition and assimilation diverse external knowledge. Diverse ties also help firms amplify its potential to gain information about technological innovations, business opportunities, sources of capital and so forth (Ahuja \& Lampert, 2001; Lane \& Lubatkin, 1998). Thus multiplexity of ties leads firms to access complimentary resources (Burt, 1992). Hence, diverse ties help on augment potential absorptive capacity.

As already mentioned, in the light of ambidexterity, centrally located organizations are well positioned in terms of reaping benefits of knowledge spillovers, information flows and innovations by peripheral actors (Bell, 2005; W. M. Cohen \& D. A. Levinthal, 1990; Walter. W Powell, et al., 1996; Soh, 2003). But for very large or small networks, centrality leads to zero or diminishing returns on potential absorptive capacity. When the size of a network gets bigger, centrality imposes information overload, thereby reducing the information processing capacity of the organization. As already stated (W. M. Cohen \& D. Levinthal, 1990), absorptive capacity is information processing capacity at the organizational level, we pose that for larger networks centrality is counterproductive to potential absorptive capacity. Similarly, when the network is sparse, the influx of information may be comprehensive enough to increase an organizations absorptive capacity. Thus, there is an optimal size of a network under which the positive effects of multiplexity does not outweigh the positive effects of centrality on potential absorptive capacity. This leads us is to propose.

\section{Proposition 2a: External networks through multiplexity and centrality affects a firm's potential absorptive capacity. Such that multiplexity positively affects and centrality has an inverted $u$-shaped relationship with potential absorptive capacity.}

Our position on the relationship between multiplexity of ties on realized absorptive capacity is quite different from what we posited on potential absorptive capacity. While informal mechanisms help in exchanging ideas, formal mechanisms are systematic for exploitation of transformation of knowledge into operations (Zahra \& George, 2002). Diverse ties bring new insights and consequences to acquired knowledge, but to boost the realized absorptive capacity, one needs the diversity in the light of systematic and formal approach. This is similar to Duncan's (1976) argument that organizations need to work on a dual mode to be innovative. During initiation, it should have low formalization, low central control, and highly complex organization of entities (subunits within organizations, other firms and also innovation engines). During implementation, however, the organization must work under high formalization, high central control, and low complexity of organization of entities. Thus, multiplexity or diversity of ties can have a positive effect of realized absorptive capacity only if pursued under the lens of formal, mechanistic mechanisms.

Centrality has a more positive impact on realized absorptive capacity than it has on potential absorptive capacity. It can be the means to keep the formal mechanism in place necessary to achieve realized absorptive capacity. For instance, in a dense network, when it is necessary to exploit and transform knowledge, centrality helps in filtration required to check in multiple influx that might lead to digression. While the influx of ideas is necessary for potential absorptive capacity, where multidimensional external view adds organizational knowledge, during exploitation or transformational phase such influx will cause result foray, compromising on the realized absorptive capacity.

Proposition 2b: External networks through Multiplexity and centrality affects a firm's realized absorptive capacity. Such that, multiplexity positively affects realized absorptive capacity only under the lens of formal mechanisms, and centrality has a positive effect of realized absorptive capacity.

\subsubsection{Internal Networks and Absorptive Capacity}

While discussing the impact of internal networks on absorptive capacity, we will hold the impact of external networks on ambidexterity, constant. An organic structure is thought to be desirable in promoting absorptive capacity because such a structure better enables people to solve unstructured problems quickly and well (Chen, 2004; W. M. Cohen \& D. Levinthal, 1990; Jansen, et al., 2005b). Since structure and collaboration are essential elements of intraorganizational network, we can conclude that networks within an organization can affect its absorptive capacity. While discussing the impact of internal networks on absorptive capacity we hold the impact of external networks on absorptive capacity constant.

Absorptive capacity is dependent on cross-functional interfaces, organizational networks and socialization (Jansen, 2005; Jansen, et al., 2005b; Szulanski, 1996; Todorova \& Durisin, 2007; Zahra \& George, 2002). Past research has shown the 
effect of combinative capabilities on absorptive capacity (Kogut \& Zander, 1992; Lane, et al., 2006; Lane \& Lubatkin, 1998; Lane, et al., 2001; Teece, Pisano, \& Shuen, 1997; Todorova \& Durisin, 2007; Van den Bosch, Volberda, \& Boer, 1999; Zahra \& George, 2002). Organizational mechanisms associated with coordination capabilities (cross functional interfaces, participation in decision making and job rotation), systems capabilities (formalization and routinization), and socialization capabilities (connectedness and socialization tactics) affect potential and realized absorptive capacity (Jansen, 2005; Jansen, et al., 2005b). In our definition of internal networks, we specified that it comprises of organizational structure, top management and behavioral context. Further, from an intraorganizational standpoint, these three aspects could be related to coordination capabilities, systems capabilities and socialization capabilities (Jansen, 2005; Jansen, et al., 2005b). Essentially, formalization and routinization is a part of organizational structure. Density of linkages or connectedness and socialization tactics serves as the dual purpose of performance and socialization of behavioral context (Gibson \& Birkinshaw, 2004). Participation of subordinates in decision making touches both organization structure (flatness) and top management team, through behavioral integration. Job-rotation allows enhancing redundancy as well as diversity of backgrounds, to increase problem-solving skills, and to develop organizational contacts (W. M. Cohen \& D. A. Levinthal, 1990; Jansen, et al., 2005b). This is again, not possible without encouragement from top management. Cross functional interface between units, increases cross-functional absorptive capacity (Clark \& Fujimoto, 1987; W. M. Cohen \& D. Levinthal, 1990). Cross functional interface cannot exist without behavioral integration from top management.

Cross-functional interfaces, job rotation, participation in decision have a positive relationship, while, formalization, routinization, connectedness and socialization has a negative relationship with potential absorptive capacity (Jansen, et al., 2005b; Lane, et al., 2006; Lane, et al., 2001; Todorova \& Durisin, 2007). Thus, top management teams (job rotation, participation, cross-functional: positive) have a positive relation, behavioral context (socialization, connectedness: negative) and organization structure (routinization, formalization: negative) have a negative impact potential absorptive capacity. Cross-functional interfaces, job rotation, formalization, routinization, connectedness and socialization tactics have a positive relationship, while participation in decision making has a negative relationship with realized absorptive capacity (Jansen, et al., 2005b; Zahra \& George, 2002). Thus, top management teams (cross-functional interfaces, job rotation: positive; participation in decision making: negative) and organizational structure (formalization, routinization: positive) has a mixed impact, while behavioral context (connectedness and socialization: positive) has a positive impact on realized absorptive capacity. Please see table 3 on how we have translated (Jansen, et al., 2005b) capabilities into dimensions of Internal Network.

$<$ Table 3 about here $>$

Proposition 2c: Internal networks affect an organization's potential absorptive capacity. Such that cross-functional interfaces, job rotation, participation in decision have a positive relationship, while, formalization, routinization, connectedness and socialization have a negative relationship with potential absorptive capacity.

Proposition 2d: Internal networks affect an organization's realized absorptive capacity. Such that cross-functional interfaces, job rotation, formalization, routinization, connectedness and socialization tactics have a positive relationship, while participation in decision making has a negative relationship with realized absorptive capacity

\subsubsection{Absorptive Capacity and Ambidexterity}

Firms focusing on acquisition and assimilation of new external knowledge (i.e., potential absorptive capacity) are able to continually renew their knowledge stock, but they may suffer from the costs of acquisition without gaining benefits from exploitation (Zahra \& George, 2002). Conversely, firms focusing on transformation and exploitation (realized absorptive capacity) may achieve short-term profits through exploitation but fall into a competence trap (Ahuja \& Lampert, 2001) and may not be able to respond to environmental changes. Realized absorptive capacity is likely to influence performance through product and process innovation (Jansen, 2005; Jansen, et al., 2005b; Todorova \& Durisin, 2007; Van den Bosch, et al., 1999; Zahra \& George, 2002). Transformation, for instance, facilitates the combination of knowledge and the development of new perceptual schemas and proposals for changes to existing products, processes, and technologies (Todorova \& Durisin, 2007; Van den Bosch, et al., 1999). In addition, exploitation underlying a unit's realized absorptive capacity converts knowledge into products, services, and technologies. In this way, a firm's realized absorptive capacity is vital to a unit's innovation process and contributes to both exploratory and exploitative innovations (Jansen, 2005; Jansen, et al., 2005b; Todorova \& Durisin, 2007; Van den Bosch, et al., 1999). 
Transformation and exploitation processes may be aimed at deepening existing knowledge and skills, and improving efficiency (Jansen, 2005; Lane, et al., 2006; Lane \& Lubatkin, 1998; Lane, et al., 2001). In this way, realized absorptive capacity helps organizational units to refine existing processes (Zahra \& George, 2002) and reduce associated costs (Jansen, 2005; Jansen, et al., 2005a). Additionally, realized absorptive capacity may also be aimed at developing and applying newly acquired external knowledge to pursue exploratory innovations (Jansen, 2005; Jansen, et al., 2005a). Exploratory innovations originate from combining and interpreting existing and newly acquired external knowledge in a different manner (Henderson \& Clark, 1990; Kogut \& Zander, 1992). Thus, one can argue that realized absorptive capacity is positively associated with its exploitative as well as exploratory innovation. As we mentioned earlier, the balance between exploration and exploitation is ambidexterity which leads us to posit that realized absorptive capacity leads to ambidexterity.

Proposition 2e: Realized absorptive capacity, through its ability to transformation and exploitation of external knowledge positively affects ambidexterity.

Apart from the contribution of realized absorptive capacity toward explorative innovation (exploration segment of ambidexterity), potential absorptive capacity becomes critical to renew a firm's knowledge stock, and develop innovative outcomes that differ substantially from existing products, services, and technologies (Jansen, 2005; Jansen, et al., 2005b; Todorova \& Durisin, 2007; Van den Bosch, et al., 1999). Explorative innovations are radical innovations place a sizeable premium on assimilative ability of new external knowledge (Henderson \& Clark, 1990; Jansen, 2005; Jansen, et al., 2005a, 2005b). Assimilative ability of external knowledge is an attribute of potential absorptive capacity (Zahra \& Nielsen, 2002). Because exploratory innovations require new knowledge or departure from existing knowledge (Levinthal \& March, 1993; McGrath, 2001), the acquisition and assimilation of new external knowledge contributes to a firm's ability to pursue exploratory innovations (Jansen, 2005; Jansen, et al., 2005a, 2005b; Zahra \& George, 2002). Conversely, without applying newly acquired and assimilated new external knowledge, organizational units are not able to pursue exploratory innovations successfully (Jansen, et al., 2005a, 2005b; Van den Bosch, et al., 1999; Zahra \& George, 2002). Thus, a firm's potential absorptive capacity positively moderates the impact of realized absorptive capacity on exploratory innovations. Although, potential absorptive capacity may increase newly acquired external knowledge, exploitative innovations build on existing knowledge and are outcomes of deepening and broadening existing knowledge and skills (Jansen, 2005; Jansen, et al., 2005b; Van den Bosch, et al., 1999; Zahra \& George, 2002). The development of a firm's potential absorptive capacity, therefore, may hinder the efficient transformation and exploitation of knowledge (Jansen, 2005; Jansen, et al., 2005b; Van den Bosch, et al., 1999; Zahra \& George, 2002). In other words, when organizations increase their potential absorptive capacity, they decrease the impact of realized absorptive capacity on exploitative innovations. From an intraorganizational standpoint, the several aspects of coordination, system and socialization capability that increases potential absorptive capacity, runs counter to realized-absorptive capacity. Also, to increase potential absorptive capacity organization needs low formalization and high diverse networks, with moderate centrality, whereas for realized absorptive capacity one needs diverse networks under the lens of high formalization with high centrality. Resources for acquisition and assimilation of new knowledge (for exploration) are different for exploitive innovations where one needs resources for with improvements to existing products, services, and technologies. Thus, organizations that increase their potential absorptive capacity may hinder organizational tasks or operations to efficiently develop exploitative innovations (Jansen, 2005; Jansen, et al., 2005b). Therefore, potential absorptive capacity negatively moderates the relationship between realized absorptive capacity and a unit's exploitative innovations. Combining the moderation effect of potential absorptive capacity on the effect of realized absorptive capacity on exploration and exploitation we get:

Proposition $2 f$. Potential absorptive capacity positively moderates the relationship between realized absorptive on the explorative dimension of ambidexterity, and negatively moderates the relation between realized absorptive capacity on exploitative dimension on ambidexterity.

\section{Conclusions and Implications}

\subsection{Theoretical and Practical Implications}

In the paper's introduction we suggested that a multidimensional conceptualization of ambidexterity by linking it to absorptive capacity and networks will advance theoretical knowledge. Past works on these three constructs have usually concentrated on two of the three aspects, leaving room for discussions and curiosity to see how the three construct affect each other. In the simplest terms, ambidexterity is balancing between exploitation of existing competencies, technologies and markets while exploring newer competencies, technologies and markets. To explore newer frontiers firms should be able to increase its capacity to absorb and assimilate new information, that is increase its absorptive capacity. Sources of new competencies, technologies are often outside the firm's existing boundaries. So external networks become 
imperative in expanding knowledge, which is complimentary to the firms existing stock. However, external networks may cripple a firm with information overload, and success often times lie in the firm's ability to develop and routinize information filters, internally. Thus, ambidexterity, absorptive capacity and networks are inextricably linked, their relations are far from simple, rather quite equivocal, as depicted in the theoretical model. We believe an integral view will help us a more comprehensive understanding on the antecedents of ambidexterity and their interplay with each other. This is particularly important since there is a continued theoretical interest in ambidexterity, whereby the assumptions and boundary conditions need to be assessed, and the interplay between the antecedents and moderators need to be evaluated.

From a theoretical standpoint, this paper advances our understanding of the various facets of networks, and absorptive capacity that lead to ambidexterity. In fact, while all these factors do explain, ambidexterity, they are very much dependent on each other. Although ambidexterity is the central construct of this paper, yet our discussions on the relationships between networks and absorptive capacities helped us getting a more comprehensive view. This work merges the gap between three constructs of interests whereby research in each area can enrich themselves by incorporating concepts from each other.

While, there has been disjoint attempts to integrate networks with absorptive capacity, networks with ambidexterity, and absorptive capacity with ambidexterity, this work opens door to include all three dimensions of organizational renewal. Research on networks can see increase in absorptive capacity and attainment exploration of emerging markets and technologies as a positive outcome. This study also extends our understanding of knowledge transfer through integration of complimentary knowledge and technologies, especially absorptive capacity and relative absorptive capacity (W. M. Cohen \& D. A. Levinthal, 1990; Lane \& Lubatkin, 1998). Research on relative absorptive suggests that a firm's ability to learn from its partner in a network is positively affected by similarity in their knowledge bases and structures. The construct of relative absorptive capacity should be expanded to include complimentarily of firm's knowledge bases (Makri, Hitt, \& Lane, 2010). Future research on absorptive capacity can use ambidexterity as context to see how relative absorptive capacity gets affected when technologies are distinct and the entities involved in the network are from different industries. We are confident that this model can pave way for new research by adding more comprehensive dimensions to view the outcome.

There are a number of practical lessons that this line of research can potentially offer to those managing firms. For example, this model suggests that for a firm to remain competitive in a globally competitive environment it must do a number of things effectively. First, firms must create an environment that fosters knowledge sharing and diffusion through deployment of a number of internal mechanisms in regards to organizational structure, top management teams, coordination and socialization capabilities and so forth. Second, firms must forge alliances with external partners to access resources towards that enable them to balance exploration and exploitation. Both these activities will lead to its ability to increase its absorptive capacity and ability to explore new areas and exploit current opportunities. Third, firms must be serious about forging alliances with academics and research organizations that do fundamental research and leveraging these relationships in ways that enable them to increase their potential and realized absorptive capacity and ultimately ambidexterity.

\subsection{Limitations}

All work has limitations. In this work we treated ambidexterity and absorptive capacity as two distinctive constructs with no overlap. Although we have identified the causal relationships between the two constructs, but for matter of theoretical simplicity we are treating them as distinct. Further, we only underscored the effect of internal networks as a moderator between external networks and ambidexterity. There can be a direct causality between internal networks and ambidexterity. Such theoretical clarity can only arise when backed up by empirical evidence. In underscoring the relationship between external networks and absorptive capacity, we held internal networks constant, and vice versa. Lastly, in posing our model we have assumed that the operating environment in terms of turbulence, complexity and dynamism remained constant. Future research should be geared towards - (a) effect of internal and external networks on absorptive capacities in each others' confluence, rather than independence, (b) direct effect of internal networks on ambidexterity, (c) effect of operating environment on the posited relationships, and (d) construct overlap between ambidexterity and absorptive capacity.

\subsection{Future Research}

Before these or any other lessons can be acted upon with confidence, much research remains to be done and we hope that this work sets forth a useful path for research in this area. Each of the propositions offered in this paper opens doors for research across multiple areas. Further, this paper opens the opportunity for research in both positivist and interpretivist paradigms. Surveys or secondary data sets could be used to conduct positivist research in order to test the 
propositions, while detailed case studies of specific firms in specific industries under certain circumstances may aid in attaining an interpretivist understanding of ambidexterity within firms in situ. Detailed studies could also be conducted in order to test specific relations between constructs.

\section{References}

Abernathy, W. J., \& Utterback, J. M. (1978). Patterns of industrial innovation. Technology Review, 80(7), 40-47.

Adler, P. S., Goldoftas, B., \& Levine, D. I. (1999). Flexibility versus Efficiency? A Case Study of Model Changeovers in the Toyota Production System. Organization Science, 10(1), 43-68. doi:10.1287/orsc.10.1.43, http://dx.doi.org/10.1287/orsc.10.1.43

Ahuja, G. (2000). Collaboration Networks, Structural Holes, and Innovation: A Longitudinal Study. Administrative Science Quarterly, 45(3), 425-455. doi:10.2307/2667105, http://dx.doi.org/10.2307/2667105

Ahuja, G., \& Katila, R. (2001). Technological acquisitions and the innovation performance of acquiring firms: a longitudinal study. Strategic Management Journal, 22(3), 197-220. doi:10.1002/smj.157,

http://dx.doi.org/10.1002/smj.157

Ahuja, G., \& Lampert, C. M. (2001). Entrepreneurship in the large corporation: A longitudinal study of how established firms create breakthrough inventions. Strategic Management Journal, 22(6/7), 521-543. doi:10.1002/smj.176, http://dx.doi.org/10.1002/smj.176

Alavi, M., \& Leidner, D. E. (2001). Knowledge management and knowledge management systems: Conceptual foundations and research issues. MIS Quarterly, 25(1), 107-136. doi:10.2307/3250961, http://dx.doi.org/10.2307/3250961

Ariño, A., \& Reuer, J. J. (2006). Strategic alliances: Governance and contracts. New York: Palgrave Macmillan.

Barney, J. B. (1991). Firm resources and sustained competitive advantage. Journal of Management, 17(1), 99-120. doi:10.1177/014920639101700108, http://dx.doi.org/10.1177/014920639101700108

Barringer, B., \& Harrison, J. (2000). Walking a tightrope: Creating value through interorganizational relationships. Journal of Management, 26(3), 367-403. doi:10.1177/014920630002600302,

http://dx.doi.org/10.1177/014920630002600302

Baum, J. A. C., Calabrese, T., \& Silverman, B., S. (2000). Don't go it alone: Alliance network composition and startups' performance in Canadian biotechnology. Strategic Management Journal, 21(3), 267-294. doi:10.1002/(SICI)1097-0266(200003)21:3<267::AID-SMJ89>3.0.CO;2-8, http://dx.doi.org/10.1002/(SICI)1097-0266(200003)21:3\%3C267::AID-SMJ89\%3E3.0.CO;2-8

Beckman, C. M., \& Haunschild, P. R. (2002). Network learning: The effects of partners' heterogeneity of experience on corporate acquisitions. Administrative Science Quarterly, 47(1), 92-124. doi:10.2307/3094892, http://dx.doi.org/10.2307/3094892

Bell, G., G. (2005). Clusters, networks, and firm innovativeness. Strategic Management Journal, 26(3), 287-295. doi:10.1002/smj.448, http://dx.doi.org/10.1002/smj.448

Benner, M. J., \& Tushman, M. L. (2003). Exploitation, exploration, and process management: The productivity dilemma revisited. Academy of Management Review, 28(2), 238-256. doi:10.2307/30040711, http://dx.doi.org/10.2307/30040711

Birkinshaw, J., \& Gibson, C. (2004). Building ambidexterity into an organization. Sloan Management Review, 45(4), $46-55$

Birkinshaw, J., Hood, N., \& Young, S. (2005). Subsidiary entrepreneurship, internal and external competitive forces, and subsidiary performance. International Business Review, 14(2), 227-248. doi:10.1016/j.ibusrev.2004.04.010, http://dx.doi.org/10.1016/j.ibusrev.2004.04.010

Bodwell, W., \& Chermack, T. J. (2009). Organizational ambidexterity: Integrating deliberate and emergent strategy with scenario planning. Technological Forecasting and Social Change, 77(2), 193-202. doi:10.1016/j.techfore.2009.07.004, http://dx.doi.org/10.1016/j.techfore.2009.07.004

Brass, D. J., Galaskiewicz, J., \& Greve, H. R. (2004). Taking stock of networks and organizations: A multilevel perspective. Academy of Management Journal, 47(6), 795-817. doi:10.2307/20159624,

http://dx.doi.org/10.2307/20159624

Brikinshaw, J., \& Gibson, C. (2004). Building Ambidexterity into an organization. Sloan Management Review, 45(4), $46-55$ 
Burgelman, R., A., \& Grove, A. S. (1996). Strategic dissonance. California Management Review, 38(2), 8-28.

Burgelman, R. A. (2002). Strategy as vector and the inertia of coevolutionary lock-in. Administrative Science Quarterly, 47(2), 325-357. doi:10.2307/3094808, http://dx.doi.org/10.2307/3094808

Burgelman, R. A., Christensen, C. M., \& Wheelright., S. C. (2006). Strategic management of technology and innovation. New York: McGraw Hill Irwin.

Burt, R. S. ( 1992). Structural holes: The social structure of competition. Cambridge, MA: Harvard University Press.

Chen, C. J. (2004). The effects of knowledge attribute, alliance characteristics, and absorptive capacity on knowledge transfer performance. R\&D Management, 34(3), 311-321. doi:10.1111/j.1467-9310.2004.00341.x, http://dx.doi.org/10.1111/j.1467-9310.2004.00341.x

Christensen, C. M. (1992a). Exploring the limits of the technology s-curve. Part I: Component technologies. Production and Operations Management, 1(4), 334-357. doi:10.1111/j.1937-5956.1992.tb00001.x, http://dx.doi.org/10.1111/j.1937-5956.1992.tb00001.x

Christensen, C. M. (1992b). Exploring the limits of the technology s-curve. Part II: Architectural technologies. Production and Operations Management, 1(4), 358-366. doi:10.1111/j.1937-5956.1992.tb00002.x, http://dx.doi.org/10.1111/j.1937-5956.1992.tb00002.x

Clark, K. B., \& Fujimoto, T. (1987). Overlapping problem-solving in product development. Cambridge, MA: Harvard University Press.

Cohen, W. M., Florida, R., Randazzes, L., \& Walsh, J. (1998). Industry and the academy: Uneasy partners in the cause of technological advance. In R. Noll (Ed.), Challenges to Research Universities (pp. 171-200). Washington, DC: The Brookings Institution.

Cohen, W. M., \& Levinthal, D.A. (1990). Absorptive capacity: A new perspective on learning and innovation. Administrative Science Quarterly 35(1), 128-152. doi:10.2307/2393553, http://dx.doi.org/10.2307/2393553

Cohen, W. M., Nelson, R. R., \& Walsh, J. P. (2002). Links and impacts: The influence of public research on industrial R\&D. Management Science, 48(1), 1-23. doi:10.1287/mnsc.48.1.1.14273,

http://dx.doi.org/10.1287/mnsc.48.1.1.14273

Collin, J. C., \& Porras, J. I. (1997). Built to last: Successful habits of visionary companies. New York: Harper Business.

Collin, J. C., \& Porras, J. I. (1999). Built to Last. Successful habits of visionary companies: Random house business Books.

Dess, G. G., \& Beard, D. W. (1984). Dimensions of organizational task environments. Administrative Science Quarterly, 29(1), 52-73. doi:10.2307/2393080, http://dx.doi.org/10.2307/2393080

Duncan, R. B. (1976). The ambidextrous organization: Designing dual structures for innovation. The Management of Organization: Strategy and Implementation, 1, 167-188.

Dyer, J. H., \& Singh, H. (1998). The relational view: Cooperative strategy and sources of interorganizational competitive advantage. Academy of Management Review, 23(4), 660-679. doi:10.2307/259056, http://dx.doi.org/10.2307/259056

Eisenhardt, K. M. (2000). Paradox, Spirals, Ambivalence: The New Language of Change and Pluralism. Academy of Management Review, 25(4), 703-705

Galunic, D. C., \& Eisenhardt, K. M. (1996). The evolution of intracorporate domains: Divisional charter losses in high-technology, multidivisional corporations. Organization Science, 7(3), 255-282. doi:10.1287/orsc.7.3.255, http://dx.doi.org/10.1287/orsc.7.3.255

Gersick, C. J. G. (1991). Revolutionary change theories: A multilevel exploration of the punctuated equilibrium paradigm. Academy of Management Review, 16(1), 10-36. doi:10.2307/258605, http://dx.doi.org/10.2307/258605

Gibson, C. B., \& Birkinshaw, J. (2004). The antecedents, consequences, and mediating: Role of organizational ambidexterity. Academy of Management Journal, 47(2), 209-226. doi:10.2307/20159573, http://dx.doi.org/10.2307/20159573

Gnyawali, D. R., He, J., \& Madhvan, R. (2006). Impact of co-opetition on firm competitive behavior: An empirical Analysis. Journal of Management, 32(4), 507-530. doi:10.1177/0149206305284550,

http://dx.doi.org/10.1177/0149206305284550

Grove, A. S. (1996). Only the paranoid survives: Exploit the crisis point that challenge every company and career. New York: Doubleday Dell Publishing Group, Inc.

Gulati, R. (1998). Alliances and networks. Strategic Management Journal, 19(4), $293-317$. doi:10.1002/(SICI)1097-0266(199804)19:4<293::AID-SMJ982>3.0.CO;2-M, 
http://dx.doi.org/10.1002/(SICI)1097-0266(199804)19:4\%3C293::AID-SMJ982\%3E3.0.CO;2-M

Gulati, R., \& Gargiulo, M. (1999). Where do interorganizational networks come from? American Journal of Sociology, 104(5), 1439-1493. doi:10.1086/210179, http://dx.doi.org/10.1086/210179

Gulati, R., \& Kletter, D. (2005). Shrinking core, expanding periphery: The relational architecture of high performing organizations. California Management Review, 47(3), 77-104.

Gulati, R., Nohria, N., \& Zaheer, A. (2000). Strategic networks. Strategic Management Journal, 21(3), 203-215. doi:10.1002/(SICI)1097-0266(200003)21:3<203::AID-SMJ102>3.0.CO;2-K, http://dx.doi.org/10.1002/(SICI)1097-0266(200003)21:3\%3C203::AID-SMJ102\%3E3.0.CO;2-K

Gupta, A. K., Tesluk, P. E., \& Taylor, S. M. (2007). Innovation at and across multiple levels of analysis. Organization Science, 18(6), 889-897. doi:10.1287/orsc.1070.0337,

http://dx.doi.org/10.1287/orsc.1070.0337

Hamel, G., \& Getz, G. (2004 ). Funding growth in an age of austerity. Harvard Business Review, 82(7-8), 76-84.

Hamel, G., \& Prahalad, C. K. (2002). Competing for the future. New Delhi: Tata McGraw Hill Edition.

Handy, C. (1990). The age of unreason. In T. K. Srikantaiah \& M. E. D. Koenig (Eds.), Knowledge management: For the Information Professional New Jersey: ASIS Monograph series.

Hansen, M. T., \& Birkinshaw, J. (2007). The innovation value chain. Harvard Business Review, 85(6), 121-130.

He, Z.-L., \& Wong, P.-K. (2004). Exploration vs. Exploitation: An Empirical Test of the Ambidexterity Hypothesis. Organization Science, 15(4), 481-494. doi:10.1287/orsc.1040.0078,

http://dx.doi.org/10.1287/orsc.1040.0078

Henderson, R. M., \& Clark, K. B. (1990). Architectural innovation: The reconfiguration of existing product technologies and the failure of established firms. Administrative Science Quarterly, 35(1), 9-30. doi:10.2307/2393549, http://dx.doi.org/10.2307/2393549

Hill, S. A., \& Birkinshaw, J. (2006). Ambidexterity in corporate venturing: Simultaneously using existing and building new capabilities. Paper presented at the Academy of Management Meeting, Atlanta, GA.

Huber, G. P., \& Glick, W. H. (1993). Organizational change and redesign: ideas and insights for improving performance. New York: Oxford University Press.

Huygens, M., Van Den Bosh, F. A. J., Volberda, H. W., \& Baden-Fuller, C. (2001). Co-evolution of firm capabilities and industry competition: Investigating the music Industry. Organization Studies, 22(6), 791-1011. doi:10.1177/0170840601226004, http://dx.doi.org/10.1177/0170840601226004

Jansen, J. (2005). Ambidextrous organizations: A multiple-level study of absorptive capacity, exploratory and exploitative innovation, and performance. Unpublished Unpublished doctoral dissertation. Erasmus Research Institute of Management, Erasmus University.

Jansen, J., Vanden Bosch, F. A. J., \& Volberda, H. W. (2005a). Exploratory innovation, exploitive innovation and ambidexterity: The impact of environmental and organizational antecedents. Schmalenbach Business Review, 57, 351-363.

Jansen, J., Vanden Bosch, F. A. J., \& Volberda, H. W. (2005b). Managing potential and realized absorptive capacity: How do organizational antecedents matter? . Academy of Management Journal, 48(5), 999-1015.

Jansen, J., Vanden Bosch, F. A. J., \& Volberda, H. W. (2006). Exploratory innovation, exploitive innovation and performance: Effects of organizational antecedents and environmental moderators. Management Science, 52(11), 1661-1674. doi: $10.1287 / \mathrm{mnsc} .1060 .0576$,

http://dx.doi.org/10.1287/mnsc.1060.0576

Klein, R., Rai, A., \& Straub, D. W. (2007). Competitive and cooperative positioning in supply chain logistics relationships. Decision Sciences, 38(4), 1-38. doi:10.1111/j.1540-5915.2007.00172.x, http://dx.doi.org/10.1111/j.1540-5915.2007.00172.x

Kogut, B., \& Zander, U. (1992). Knowledge of the firm, combinative capabilities, and the replication of technology. Organization Science, 3(3), 383-397. doi:10.1287/orsc.3.3.383,

http://dx.doi.org/10.1287/orsc.3.3.383

Koka, B. R., \& Prescott, J. E. (2002). Strategic alliances as social capital: a multidimensional view. Strategic Management Journal, 23(9), 795-816. doi:10.1002/smj.252,

http://dx.doi.org/10.1002/smj.252 
Lane, P. J., Koka, B. R., \& Pathak, S. (2006). The Reification of Absorptive Capacity: A Critical Review and Rejuvenation of the Construct. Academy of Management Review, 31(4), 833-863

Lane, P. J., \& Lubatkin, M. (1998). Relative absorptive capacity and interorganizational learning. Strategic Management Journal, 19(5), 461-477. doi:10.1002/(SICI)1097-0266(199805)19:5<461::AID-SMJ953>3.0.CO;2-L,

http://dx.doi.org/10.1002/(SICI)1097-0266(199805)19:5\%3C461::AID-SMJ953\%3E3.0.CO;2-L

Lane, P. J., Salk, J. E., \& Lyles, M. A. (2001). Absorptive capacity, learning, and performance in international joint ventures. Strategic Management Journal, 22(12), 1139-1161. doi:10.1002/smj.206, http://dx.doi.org/10.1002/smj.206

Lavie, D., \& Rosenkopf, L. (2006). Balancing exploration and exploitation in alliance formation. Academy of Management Journal, 49(4), 797-818.

Levinthal, D. A. (1997). Adaptation on rugged landscapes. Management Science, 43(7), 934-950. doi:10.1287/mnsc.43.7.934, http://dx.doi.org/10.1287/mnsc.43.7.934

Levinthal, D. A., \& March, J. G. (1993). The myopia of learning. Strategic Management Journal, 14, 95-112. doi:10.1002/smj.4250141009, http://dx.doi.org/10.1002/smj.4250141009

Lewin, A. Y., \& Volberda, H. W. (1999). Prolegomena on coevolution: A framework for research on strategy and new organizational forms. Organization Science, 10(5), 519-534. doi:10.1287/orsc.10.5.519, http://dx.doi.org/10.1287/orsc.10.5.519

Lewis, M. W. (2000). Exploring Paradox: Toward a More Comprehensive Guide. The Academy of Management Review, 25(4), 760-776. doi:10.2307/259204, http://dx.doi.org/10.2307/259204

Lin, Y. C., Wang, L. C., \& Tserng, H. P. (2006). Enhancing knowledge exchange through web map-based knowledge management system in construction: Lessons learned in Taiwan. Automation in Construction 15(6), 693-705. doi:10.1016/j.autcon.2005.09.006,

http://dx.doi.org/10.1016/j.autcon.2005.09.006

Lubatkin, M. H., Simsek, Z., \& Veiga, J. F. (2006). Ambidexterity and performance in small- to medium-sized firms: The pivotal role of top management team behavioral integration. Journal of Management, 32(5), 646-672. doi:10.1177/0149206306290712,

http://dx.doi.org/10.1177/0149206306290712

Makri, M., Hitt, M., \& Lane, P. (2010). Complementary technologies, knowledge relatedness, and invention outcomes in high technology mergers and acquisitions. Strategic Management Journal, 31(6), 602-628.

March, J. G. (1991). Exploration and exploitation in organizational learning. Organization Science 2(1), 71-87. doi:10.1287/orsc.2.1.71, http://dx.doi.org/10.1287/orsc.2.1.71

Mata, F. J., Fuerst, W. L., \& Barney, J. B. (1995). Information technology and sustained competitive advantage: A resource-based analysis. MIS Quarterly, 19(4), 487-505. doi:10.2307/249630, http://dx.doi.org/10.2307/249630

McGrath, R. G. (2001). Exploratory learning, innovative capacity and managerial oversight. The Academy of Management Journal, 44(1), 118-131. doi:10.2307/3069340, http://dx.doi.org/10.2307/3069340

Melville, N., Kraemer, K. L., \& Gurbaxani, V. (2004). Information technology and organizational performance: An integrative model of IT-business value. MIS Quarterly, 28(2), 283-322.

Moore, J. F. (1993). Predators and prey: A new ecology of competition. Harvard Business Review, 71(3), 75-86.

Nadler, D. A., \& Tushman, M. L. (1999). The Organization of the Future: Strategic Imperatives and Core Competencies for the 21st Century. Organizational Dynamics, 28, 45-60. doi:10.1016/S0090-2616(00)80006-6, http://dx.doi.org/10.1016/S0090-2616(00)80006-6

Nahapiet, J., \& Ghoshal, S. (1998). Social capital, intellectual capital, and the organizational advantage. Academy of Management Review, 23(2), 242-266. doi:10.2307/259373,

http://dx.doi.org/10.2307/259373

Narasimhan, O., Rajiv, S., \& Dutta, S. (2006). Absorptive Capacity in High-Technology Markets: The Competitive Advantage of the Haves. MARKETING SCIENCE, 25(5), 510-524. doi:10.1287/mksc.1060.0219, http://dx.doi.org/10.1287/mksc.1060.0219

Nohria, N. (1992). Is a network perspective a useful way of studying organizations? In N. Nohria \& R. G. Eccles (Eds.), Networks and Organization: 287-301 Cambridge, MA: Harvard Business School Press.

Nohria, N., \& Eccles, R. G. (1992). Networks and organizations: Structure, form, and action. Cambridge, MA: Harvard Business School Press.

O'Reilly, C. A., III, \& Tushman, M. (2007). Ambidexterity as a Dynamic Capability: Resolving the Innovator's Dilemma. 
Stanford University Graduate School of Business Research Paper No. 1963.

O’Reilly, C. A., \& Tushman, M. L. (2004). Ambidextrous organization. Harvard Business Review 82(4), 71-81.

Oliver, A. L. (2004). Biotechnology entrepreneurial scientists and their collaborations. Research Policy, 33(4), 583-597. doi:10.1016/j.respol.2004.01.010, http://dx.doi.org/10.1016/j.respol.2004.01.010

Pfeffer, J., \& Salancik, G. R. (1978). The external control of organizations: A resource dependence perspective. New York: Harper \& Row.

Phelps, C. (2003). Technological exploration: A longitudinal study of the role of recombinatory search and social capital in alliance networks. Unpublished Unpublished dissertation. New York University.

Phelps, C. (2010). A longitudinal study of the influence of alliance network structure and composition on firm exploratory innovation. Academy of Management Journal, 53(4), 890-913.

Porter, M. E. (1998). Cluster and Competition: New agendas for firms, governments, and institutions. In M. E. Porter (Ed.), Michael Porter on competition: 213-308. Cambridge, MA: Harvard Business School Press.

Powell, W. W. (1998). Learning from collaboration: Knowledge and networks in the biotechnology and pharmaceutical industries. California Management Review, 40(3), 228-240.

Powell, W. W., Koput, K. W., \& Smith-Doerr, L. (1996). Interorganizational Collaboration and the Locus of Innovation: Networks of Learning in Biotechnology. Administrative Science Quarterly, 41(1), 116-145. doi:10.2307/2393988, http://dx.doi.org/10.2307/2393988

Provan, K. G., Fish, A., \& Sydow, J. (2007). Interorganizational networks at the network level: A review of empirical literature on whole networks. Journal of Management, 33(3), 479-516. doi:10.1177/0149206307302554, http://dx.doi.org/10.1177/0149206307302554

Raisch, S., \& Birkinshaw, J. (2008). Organizational ambidexterity: Antecedents outcomes and moderators. Journal of Management, 34(3), 275-409. doi:10.1177/0149206308316058,

http://dx.doi.org/10.1177/0149206308316058

Salman, N., \& Saives, A.-L. (2005). Indirect networks: An intangible resource for biotechnology innovation. $R \& D$ Management, 35(2), 203-215. doi:10.1111/j.1467-9310.2005.00383.x,

http://dx.doi.org/10.1111/j.1467-9310.2005.00383.x

Schilling, M. A., \& Phelps, C. C. (2007). Interfirm Collaboration Networks: The Impact of Large-Scale Network Structure on Firm Innovation. Management Science, 53(7), 1113-1126. doi:10.1287/mnsc.1060.0624, http://dx.doi.org/10.1287/mnsc.1060.0624

Scott, J. (1991). Social Network Analysis: A Handbook. Thousand Oaks, CA: Sage.

Sidhu, J., S, Commandeur, H., R, \& Volberda, H. W. (2007). The multifaceted nature of exploration and exploitation: Value of supply, demand, and spatial search for innovation. Organization Science, 18(1), 20-38. doi:10.1287/orsc.1060.0212, http://dx.doi.org/10.1287/orsc.1060.0212

Sidhu, J., S, Volberda, H. W., \& Commandeur, H., R (2004). Exploring exploration orientation and its determinants: Some empirical evidence. Journal of Management Studies, 41(6), 913-932. doi:10.1111/j.1467-6486.2004.00460.x, http://dx.doi.org/10.1111/j.1467-6486.2004.00460.x

Siggelkow, N., \& Levinthal, D. A. (2003). Temporarily Divide to Conquer: Centralized, Decentralized, and Reintegrated Organizational Approaches to Exploration and Adaptation. Organization Science, 14(6), 650-669.

Simsek, Z. (2009). Organizational ambidexterity: Towards a multilevel understanding. Journal of Management Studies, 46(4), 597-624. doi:10.1111/j.1467-6486.2009.00828.x,

http://dx.doi.org/10.1111/j.1467-6486.2009.00828.x

Simsek, Z., Heavey, C., Veiga, J. F., \& Souder, D. (2009). A Typology for Aligning Organizational Ambidexterity's Conceptualizations, Antecedents, and Outcomes. Journal of Management Studies, 46(5), 864-894. doi:10.1111/j.1467-6486.2009.00841.x, http://dx.doi.org/10.1111/j.1467-6486.2009.00841.x

Smith, W. K., \& Tushman, M. L. (2005). Managing Strategic Contradictions: A Top Management Model for Managing Innovation Streams. Organization Science, 16(5), 522-536. doi:10.1287/orsc.1050.0134, http://dx.doi.org/10.1287/orsc.1050.0134

Soh, P.-H. (2003). The role of networking alliances in information acquisition and its implications for new product performance. Journal of Business Venturing, 18(6), 727-744. doi:10.1016/S0883-9026(03)00026-0, http://dx.doi.org/10.1016/S0883-9026(03)00026-0 
Szulanski, G. (1996). Exploring Internal Stickiness: Impediments to the Transfer of Best Practice Within the Firm. Strategic Management Journal, 17, 27-43.

Teece, D. J., Pisano, G., \& Shuen, A. (1997). Dynamic capabilities and strategic management. Strategic Management Journal, 18(7), 509-533.

doi:10.1002/(SICI)1097-0266(199708)18:7<509::AID-SMJ882>3.0.CO;2-Z

http://dx.doi.org/10.1002/(SICI)1097-0266(199708)18:7\%3C509::AID-SMJ882\%3E3.0.CO;2-Z

Thompson, J. D. (1967). Organizations in action- Social Science bases of administrative theory. New York: McGraw-Hill.

Todorova, G., \& Durisin, B. (2007). Absorptive Capacity: Valuing a reconceptualization. [Article]. Academy of Management Review, 32, 774-786.

Tushman, M. L., \& O'Reilly, C. A. (1996a). Ambidextrous organizations: Managing evolutionary and revolutionary change. California management Review, 38(4).

Tushman, M. L., \& O’Reilly, C. A. (1996b). Ambidextrous organizations: Managing evolutionary and revolutionary change. California Management Review, 38(4), 8-30.

Tushman, M. L., \& O'Reilly, C. A. (2002). Winning through innovation: A practical guide to leading organizational change and renewal. Boston, MA: Harvard Business School Press.

Van den Bosch, F. A. J., Volberda, H. W., \& Boer, M. d. (1999). Coevolution of firm absorptive capacity and knowledge environment: Organizational forms and combinative capabilities. Organization Science, 10(5), 551-568. doi:10.1287/orsc.10.5.551, http://dx.doi.org/10.1287/orsc.10.5.551

Van Wijk, R. (2003). Organizing Knowledge in Internal Networks. Erasmus Research Institute of Management, Erasmus University.

Veliyath, R. (1992). Strategic planning: Balancing short-run performance and longer term prospects. Long Range Planning, 25(3), 86-97. doi:10.1016/0024-6301(92)90373-A,

http://dx.doi.org/10.1016/0024-6301(92)90373-A

Vinekar, V., Slinkman, C. W., \& Nerur, S. (2006). Can Agile and Traditional Systems Development Approaches Coexist? An Ambidextrous View. Information Systems Management, 23(3), 31 - 42.

doi:10.1201/1078.10580530/46108.23.3.20060601/93705.4,

http://dx.doi.org/10.1201/1078.10580530/46108.23.3.20060601/93705.4

Volberda, H. W. (1998). Building the flexible firm: How to remain competitive. New York: Oxford University Press.

Volberda, H. W., \& Lewin, A. Y. (2003). Co-evolutionary dynamics within and between firms: From evolution to co-evolution. Journal of Management Studies, 40(8), 2105-2130. doi:10.1046/j.1467-6486.2003.00414.x, http://dx.doi.org/10.1046/j.1467-6486.2003.00414.x

Wielemaker, M. (2003). Managing initiatives: A synthesis of the conditioning and knowledge-creating view. Erasmus University Rotterdam.

Williamson, O. E. (1991). Comparative economic organization: The analysis of discrete structural alternatives. Administrative Science Quarterly, 36(2), 269-296. doi:10.2307/2393356, http://dx.doi.org/10.2307/2393356

Yli-Renko, H., Autio, E., \& Sapienza, H. J. (2001). Social Capital, Knowledge Acquisition, and Knowledge Exploitation in Young Technology-Based Firms. Strategic Management Journal, 22(6/7), 587-613. doi:10.1002/smj.183, http://dx.doi.org/10.1002/smj.183

Zack, M. H. (1999). Developing knowledge strategy. California management Review, 41, 125-145.

Zack, M. H. (2003). Rethinking knowledge based organization. Sloan Management Review, 44(4), 12-17.

Zahra, S. A., \& George, G. (2002). Absorptive capacity: A review, reconceptualization, and extension. Academy of Management Review, 27(2), 185-203. doi:10.2307/4134351,

http://dx.doi.org/10.2307/4134351

Zahra, S. A., \& Nielsen, A. P. (2002). Sources of capabilities, integration and technology commercialization. Strategic Management Journal, 23(5), 377-398. doi:10.1002/smj.229, http://dx.doi.org/10.1002/smj.229 
Table 1. Construct Definitions

\begin{tabular}{|c|l|l|}
\hline $\begin{array}{c}\text { Construct } \\
\text { name }\end{array}$ & Type & \multicolumn{1}{|c|}{ Definition } \\
\hline Ambidexterity & $\begin{array}{l}\text { Dependent } \\
\text { Variable }\end{array}$ & $\begin{array}{l}\text { The property of an organization to balance activities of exploration } \\
\text { and exploitation. }\end{array}$ \\
\hline Networks & $\begin{array}{l}\text { Independent } \\
\text { Variable }\end{array}$ & $\begin{array}{l}\text { The collective of structures, collaboration, within and between } \\
\text { organizations, and between organizations and innovation engines. } \\
\text { From an external network standpoint this includes business clusters, } \\
\text { partnerships, business ecosystems, and relationships with innovation } \\
\text { engines. From the standpoint of intraorganizational or internal } \\
\text { networks, it includes organizational structure, behavioral context, } \\
\text { and top management teams. These networks themselves become a } \\
\text { valuable resource, enabling organizational flexibility and leading to } \\
\text { self-renewal. }\end{array}$ \\
\hline Absorptive & Mediators & $\begin{array}{l}\text { The limit to the rate at which a firm can absorb scientific or } \\
\text { technological information and/or a limit to the quantity of such } \\
\text { information that can be absorbed. } \\
\text { Potential Absorptive Capacity: knowledge acquisition and } \\
\text { assimilation, captures efforts expended in identifying and acquiring } \\
\text { new external knowledge and in assimilating knowledge obtained } \\
\text { from external sources. } \\
\text { Realized Absorptive Capacity: knowledge transformation and } \\
\text { exploitation, encompasses deriving new insights and consequences } \\
\text { from the combination of existing and newly acquired knowledge, } \\
\text { and incorporating transformed knowledge into operations }\end{array}$ \\
\hline
\end{tabular}

Table 2. Propositions

\begin{tabular}{|c|c|c|}
\hline $\begin{array}{l}\text { Proposition } \\
\text { No }\end{array}$ & Antecedent & Outcome \\
\hline P1a & $\begin{array}{l}\text { External networks (Multiplexiy/ } \\
\text { Diversity) }\end{array}$ & Ambidexterity $(+)$ \\
\hline P1b & External networks (Centrality) & Ambidexterity (inverse u) \\
\hline P1c & $\begin{array}{l}\text { Internal networks (Dual structure } \\
\text { within firms) }\end{array}$ & $\begin{array}{l}\text { Moderates relationship between external networks } \\
\text { (centrality and multiplexity) on Ambidexterity }(+)\end{array}$ \\
\hline P1d & $\begin{array}{l}\text { Internal networks } \\
\text { context within firms) }\end{array}$ & $\begin{array}{l}\text { Moderates relationship between external networks } \\
\text { (centrality and multiplexity) on Ambidexterity }(+)\end{array}$ \\
\hline P1e & $\begin{array}{l}\text { Internal networks (top management } \\
\text { teams) }\end{array}$ & $\begin{array}{l}\text { Moderates relationship between external networks } \\
\text { (centrality and multiplexity) on Ambidexterity }(+)\end{array}$ \\
\hline $\mathrm{P} 2 \mathrm{a}$ & $\begin{array}{l}\text { External networks (multiplexity and } \\
\text { centrality) }\end{array}$ & $\begin{array}{l}\text { Multiplexity } \rightarrow \text { Potential absorptive capacity }(+) \\
\text { Centrality } \rightarrow \text { Potential Absorptive capacity (inverse } u \\
\text { relation) }\end{array}$ \\
\hline $\mathrm{P} 2 \mathrm{~b}$ & $\begin{array}{l}\text { External networks (multiplexity and } \\
\text { centrality) }\end{array}$ & $\begin{array}{l}\text { Multiplexity } \rightarrow \text { Realized absorptive capacity }(+) \\
\text { through formal mechanisms } \\
\text { Centrality } \rightarrow \text { Realized Absorptive capacity }(+)\end{array}$ \\
\hline $\mathrm{P} 2 \mathrm{c}$ & $\begin{array}{l}\text { Internal networks } \\
\text { Top Management teams, behavioral } \\
\text { context, and organization structure }\end{array}$ & $\begin{array}{l}\text { Potential Absorptive Capacity: } \\
\text { Top Management teams }(+) \text {, Behavioral context (-), } \\
\text { organization Structure }(-)\end{array}$ \\
\hline $\mathrm{P} 2 \mathrm{~d}$ & $\begin{array}{l}\text { Internal networks } \\
\text { Top Management teams, behavioral } \\
\text { context, and organization structure }\end{array}$ & $\begin{array}{l}\text { Realized Absorptive Capacity: } \\
\text { Top Management teams }(+/-) \text {, Behavioral context } \\
(+) \text {, organization Structure }(+)\end{array}$ \\
\hline $\mathrm{P} 2 \mathrm{e}$ & Realized absorptive capacity & Ambidexterity \\
\hline P2f & Potential Absorptive Capacity & $\begin{array}{l}\text { Moderates relation between realized absorptive } \\
\text { capacity and ambidexterity. } \\
\text { Exploration }(+) \\
\text { Exploitation }(-)\end{array}$ \\
\hline
\end{tabular}


Table 3. Capabilities translated to Internal Networks

\begin{tabular}{|c|c|c|}
\hline $\begin{array}{c}\text { Jansen et al (2005) } \\
\text { capabilities }\end{array}$ & Dimensions & Internal networks \\
\hline \multirow{2}{*}{ Coordination Capabilities } & Cross functional & \multirow{2}{*}{ Top Management Team } \\
\cline { 2 - 2 } & Job rotation & \\
\cline { 2 - 2 } & Participation & \multirow{2}{*}{ Organization Structure } \\
\hline \multirow{2}{*}{ System capabilities } & Routinization & \\
\cline { 2 - 2 } & Formalization & \multirow{2}{*}{ Behavioral context } \\
\hline \multirow{2}{*}{ Socialization Capabilities } & Socialization & \\
\cline { 2 - 2 } & connectedness & \\
\hline
\end{tabular}

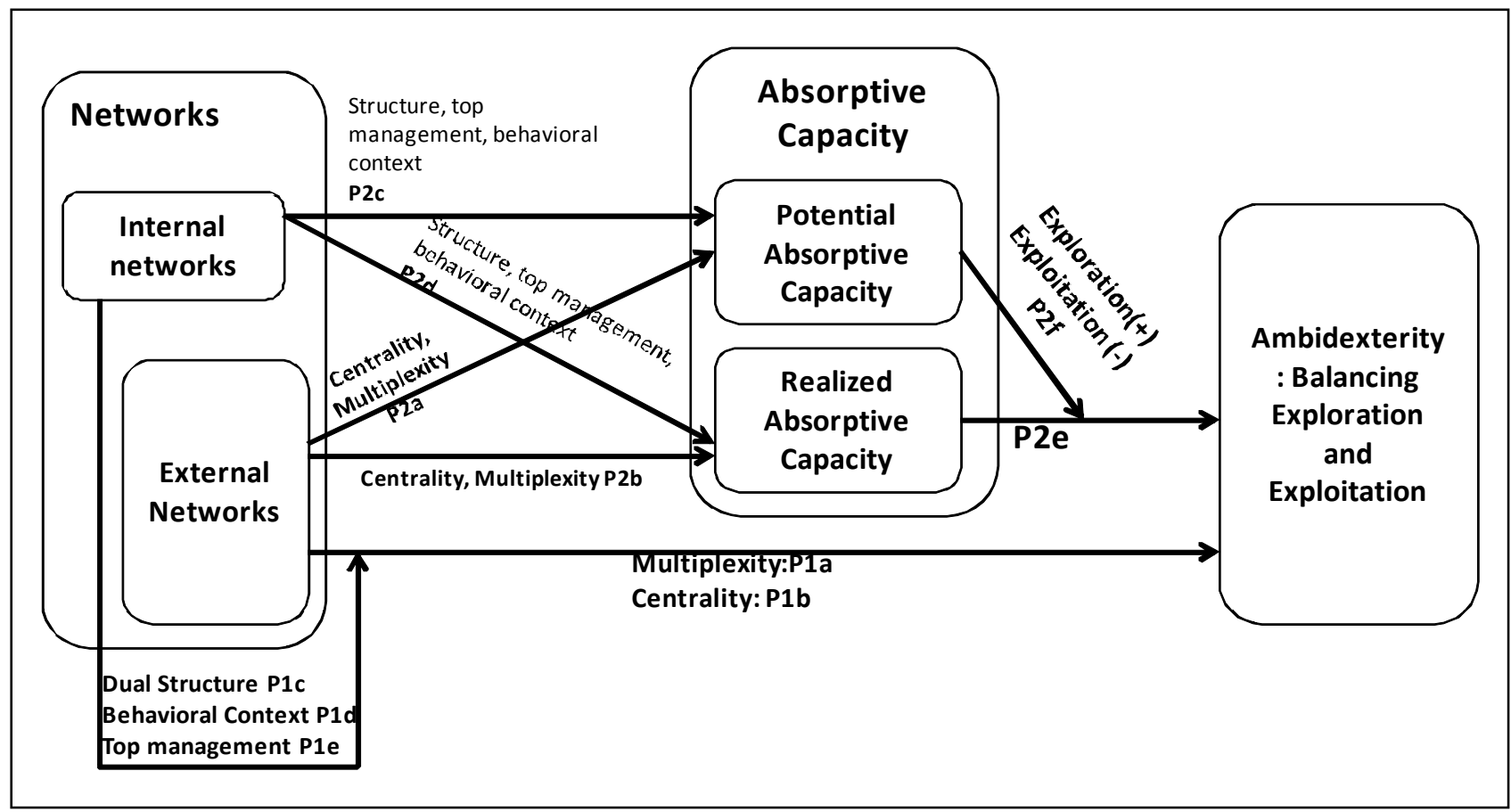

Figure 1. Theoretical Model 